\title{
Investigating Proteome and Transcriptome Defense Response of Apples Induced by Yarrowia lipolytica
}

\author{
Hongyin Zhang, ${ }^{1}$ Liangliang Chen, ${ }^{2}$ Yiwen Sun, ${ }^{1}$ Lina Zhao, ${ }^{1}$ Xiangfeng Zheng, ${ }^{1}$ Qiya Yang, ${ }^{1}$ and \\ Xiaoyun Zhang' \\ ${ }^{1}$ School of Food and Biological Engineering, Jiangsu University, Zhenjiang 212013, Jiangsu, People's Republic of China; and \\ ${ }^{2}$ Institute of Life Sciences, Jiangsu University
}

Accepted 13 February 2017.

\begin{abstract}
A better understanding of the mode of action of postharvest biocontrol agents on fruit surfaces is critical for the advancement of successful implementation of postharvest biocontrol products. This is due to the increasing importance of biological control of postharvest diseases over chemical and other control methods. However, most of the mechanisms involved in biological control remain unknown and need to be explored. Yarrowia lipolytica significantly inhibited blue mold decay of apples caused by Penicillium expansum. The findings also demonstrated that $\boldsymbol{Y}$. lipolytica stimulated the activities of polyphenoloxidase, peroxidase, chitinase, L-phenylalanine ammonia lyase involved in enhancing defense responses in apple fruit tissue. Proteomic and transcriptomic analysis revealed a total of 35 proteins identified as up- and downregulated in response to the $Y$. lipolytica inducement. These proteins were related to defense, biotic stimulus, and stress responses, such as pathogenesis-related proteins and dehydrin. The analysis of the transcriptome results proved that the induced resistance was mediated by a crosstalk between salicylic acid (SA) and ethylene/jasmonate (ET/JA) pathways. Y. lipolytica treatment activated the expression of isochorismate synthase gene in the SA pathway, which up-regulates the expression of PR4 in apple. The expression of 1-aminocyclopropane-1-carboxylate oxidase gene and ET-responsive transcription factors 2 and 4, which are involved in the ET pathway, were also activated. In addition, cytochrome oxidase I, which plays an important role in JA signaling for resistance acquisition, was also activated. However, not all of the genes had a positive effect on the SA and ET/JA signal pathways. As transcriptional repressors in JA signaling, $T I F Y 3 B$ and $T I F Y 11 B$ were triggered by the yeast, but the gene expression levels were relatively low. Taken together, $Y$. lipolytica induced the SA and ET/JA signal mediating the defense pathways by stimulating defense response genes, such as peroxidase, thaumatin-like protein, and chitinase 4-like, which are involved in defense response in apple.
\end{abstract}

The use of antagonistic yeast for biological control of pathogens has been reported to be a safe and effective method for managing postharvest diseases (Droby et al. 2016). Previous research results showed that competition for nutrients and niche

Corresponding author: H. Zhang; E-mail: zhanghongyin126@126.com

*The $e$-Xtra logo stands for "electronic extra" and indicates that one supplementary table is published online.

(c) (i) (5) $€$ (c) 2017 The Author(s) This is an open access article distributed under the CC BY-NC-ND 4.0 International license. exclusion are the most important mode of action of the yeast to inhibit the development of pathogens in the fruit wound (Spadaro and Droby 2016). Typically, mechanisms involved in the ability of yeast antagonists to inhibit postharvest pathogens include competition for nutrients and space (Jamalizadeh et al. 2011), induction of host resistance (Tian et al. 2011), oxidative response (Macarisin et al. 2010), and parasitism (MagallonAndalon et al. 2012). These mechanisms of action have been reviewed by Spadaro and Droby (2016). Among them, host resistance induced by the antagonistic yeast was considered as one of the key components by which the pathogen is inhibited. The plant recognizes the bio-elicitor induction and develops resistance to protect itself from further attacks by the pathogen.

The salicylic acid (SA) signal transduction pathway is an important pathway to acquire induced defense in many plants (Kachroo and Kachroo 2007). SA enhances the biocontrol efficacy of antagonistic yeast by inducing a significant increase in polyphenoloxidase, L-phenylalanine ammonia lyase (PAL), and $\beta$-1,3-glucanase activity in cherry fruit (Qin et al. 2003). $\mathrm{SA}$ is also involved in the expression of a range of defense pathogenesis-related (PR) proteins, such as chitinase (PR-3), $\beta$-1,3-glucanase (PR-2), and peroxidase (Qin et al. 2003). Pathogen infection stimulates plants to synthesize SA, which regulates the expression of $\mathrm{PR}$ proteins and it had been reported that PR proteins play an important role in defense against pathogenicity (Umar et al. 2016; van Loon et al. 2006). The antagonistic yeast Pichia membranaefaciens induced PR proteins in peach fruit that played an important role in the fruit resistance to pathogens (Chan et al. 2007). Moreover, the antagonistic yeast Metschnikowia fructicola up-regulated the $P R$ genes in grapefruit that played an important role in the efficacy of Metschnikowia fructicola against Penicillium digitatum (Hershkovitz et al. 2012). The generation of PR proteins is one of the important biochemical mechanisms involved in inducing plant resistance against pathogen diseases in postharvest shelf life (Charles et al. 2009; Quaglia et al. 2011; Wang et al. 2009).

Recently, studies revealed the identified PR families mainly comprise 17 groups that most often associated with plant defense response (Hoffmann-Sommergruber 2002, van Loon et al. 2006). In apple stems, expression of apple PR-5 and PR-8 genes were characterized in response to Candida oleophila and Botrytis cinerea in vitro. The results showed the PR- 8 protein has antifungal activity against fungal pathogens (Bonasera et al. 2006). The existence of $\beta$-1,3-glucanase (PR-2), chitinase (PR-3), and thaumatin-like protein (PR-5) was observed in Malus domestica leaves infected by $V$. inaequalis (Gau et al. 2004). A PR-4 gene identified from Malus domestica is involved in defense responses against Botryosphaeria dothidea (Bai et al. 2013). 
Another response pathway to biotic stresses is mediated by JA/ET signaling, which plants use to deal with the complex environmental effects caused by biotic and abiotic stresses (Santino et al. 2013). In general, JA and ET mediate responses against necrotrophs (Fujita et al. 2006; Glazebrook 2005), but some studies proved that there is crosstalk between SA and JA pathways in response to biotic stress. The crosstalk can be either mutually antagonistic or synergistic (Adie et al. 2007; Beckers and Spoel 2006; Spoel et al. 2007). In Abrabidopsis, the invasion of Botrytis cinerea induced both the SA and JA signal pathways (Ferrari et al. 2007). COII is a gene that has been proven to play an important role in the JA signal for resistance against fungi (Adie et al. 2007; Chini et al. 2007; Glazebrook 2005). A key step in the activation of induced resistance is mediated by transcription factors (TFs) and TFs control the transcriptional regulation of related defense genes. Several members of the ET-responsive TF (ERF) family have been shown that play a key role in JA-mediated response to pathogens (Berrocal-Lobo et al. 2002; Brown et al. 2003; Lorenzo et al. 2003; McGrath et al. 2005; Moffat et al. 2012). The bHLH transcription factors $M Y C 2, M Y C 3$, and MYC4 belong to the TF family; they are all involved in the JA-mediated signal resistance. The $M Y C 2$ is a key point of the JA signaling pathway that regulates the expression of different subsets of JAresponsive genes and also different responsive genes to hormone targets of JAZ repressors (Lorenzo et al. 2004; Shin et al. 2012). Several members of the WRKY TF family have been involved in specific aspects of induced responses (Petersen et al. 2000).

Antagonistic yeasts have been reported to act as bio-elicitors of fruit host resistance (Spadaro and Droby 2016). In tomato, the genes involved in metabolism, signal transduction, and stress response were up-regulated by the antagonistic yeast
Cryptococcus laurentii (Sharma et al. 2009). Rhodosporidium paludigenum activated gene expression of plant hormones, signaling transduction, stress, and defensive responses in mandarin orange. It has been reported that antifungal metabolites of mandarin orange, indeed, contribute to biocontrol enhancement of yeasts, offer fruit protection, and provide an important basis for understanding the mechanisms of resistance induction in mandarin orange (Lu et al. 2015). In previous studies, Yarrowia lipolytica significantly inhibited various fungal diseases via induced disease resistance (Groenewald et al. 2014; Yang et al. 2015). However, the mechanism of the induced disease resistance by $Y$. lipolytica is still not clear.

In the current study, the effects of $Y$. lipolytica on defenserelated enzymes such as polyphenoloxidase, peroxidase, chitinase, and PAL were investigated in apple fruit. Additionally, proteome and transcriptome of the apple wound-inoculated tissues were also investigated, to determine the mechanism and the possible pathways involved in the defense induction by the antagonist yeast and the possible signaling elicitors.

\section{RESULTS}

\section{Inhibition of Penicillium expansum infection by $Y$. lipolytica.}

The inhibitory effect on disease incidence was influenced by cell concentrations of $Y$. lipolytica (Fig. 1). The best inhibitory effect was observed using a concentration of $10^{9}$ cells per milliliter. At this concentration, the percentage of disease infection was $24.06 \%$, compared with $84.3 \%$ in the control (Fig. 1C). Lower cell yeast concentrations showed very marginal effects on disease incidence. Similarly, the disease lesion diameter was also influenced by the concentration of $Y$. lipolytica (Fig. 1D). The higher the concentration of the yeasts, the less
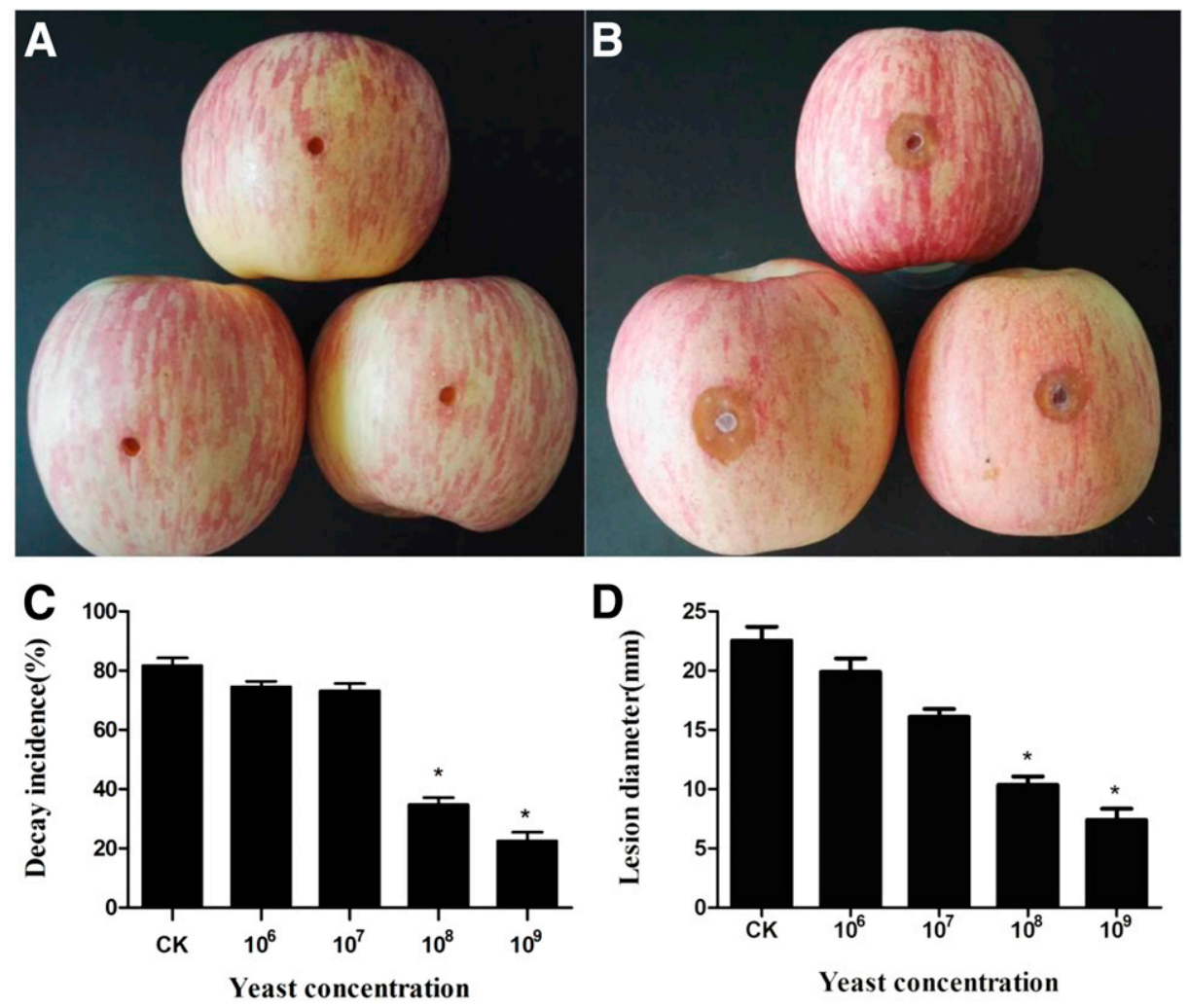

Fig. 1. Effect of Yarrowia lipolytica in mold decay of apples caused by Penicillium expansum. A, Apples inoculated with Y. lipolytica and P. expansum and stored for 5 days. B, Treatment with $P$. expansum. C, The decay incidence caused by P. expansum. D, The lesion diameter caused by $P$. expansum in apples. Asterisks $(*)$ indicate significant difference. 
expansion of the lesion diameter was evident; at a yeast concentration of $10^{9}$ cells per milliliter, the disease lesion diameter was $6.10 \mathrm{~mm}$ compared with $21.23 \mathrm{~mm}$ in the control (Fig. 1D).

\section{Effect of Y. lipolytica treatment}

on the activity of defense related enzymes.

Polyphenoloxidase (PPO), peroxidase (POD), chitinase (CHI), and PAL are the four defense-related enzymes tested in apple wound tissue in response to application of $Y$. lipolytica. As shown in Figure 2A, Y. lipolytica caused significant increased PPO activity on days 1 and 2 (20 U per gram of fresh weight), then decreased to $12 \mathrm{U}$ per gram of fresh weight on days 3 and 4 , and then, increased to $18 \mathrm{U}$ per gram of fresh weight on day 5. The PPO activity of the control was lower than that in the $Y$. lipolytica treatment at all tested time points except day 3 . The results for POD activity (Fig. 2B) indicated that POD activity of apple wound tissue significantly increased $(P<0.05)$ at all the tested time points, with the exception of day 3. The results for activities of CHI (Fig. 2C) and PAL (Fig. 2D) also revealed $Y$. lipolytica increased enzyme activities compared with the control, even through days 5 and 6 . The trends of both these two enzymes were the same in apple wounds of $Y$. lipolytica treatment and the control.

\section{Two-dimensional gel electrophoresis (2-DE) analysis} of proteins induced by $Y$. lipolytica in apples.

Protein expression levels in apple wounds treated with $Y$. lipolytica was observed to be different than the protein expression levels of the control; there were 42 proteins differentially expressed in the yeast-treated apple tissue at day 3 after inoculation (Fig. 3A and B). Using tandem mass spectrometry (MS/MS), 35 proteins that demonstrated statistically significant changes $(P<0.05)$ relative to protein abundances in treated apples were identified. Among these, 12 proteins were upregulated and 23 proteins were down-regulated. These proteins were searched with the MS/MS ion searching program MASCOT and were further assessed with MS-BLAST (Table 1). According to the method of functional annotation classification (Bevan et al. 1998), these induced proteins were mainly involved in defense reactions and stress responses (Fig. 3C).
The expression level of PR-10 (spot 5), thaumatin-like protein (PR-5) (spots 6, 7, 12, 14, and 16), and dehydrin (spots 19, 20, and 34) were increased as a result of $Y$. lipolytica treatment (Table 1).

\section{Transcription and functional analysis \\ of genes induced by $Y$. lipolytica.}

The transcriptomes of apple fruit wound tissue treated with $Y$. lipolytica and nontreated fruit tissue (control) were analyzed using RNA-Seq technology. A total of 607 DEGs (differentially expressed genes) were detected, in which 461 genes were up-regulated and 146 genes were down-regulated in the $Y$. lipolytica-treated apple tissue. Among these, 229 genes were significantly increased and 20 genes were significantly downregulated $\left(\log _{2}\right.$ fold change $\left.>2\right)$. These DEGs were clustered by gene function with Gene Ontology (GO) (Fig. 4). The biological processes contained 14 subgroups and the molecular function contained 16 subgroups. The most dynamic GO categories were those in response to biotic stimulus and defense response. The abiotic stress genes under the biological process category were the important genes involved in induced resistance caused by $Y$. lipolytica .

\section{Expression of TFs in SA and JA/ET signal pathways induced by $Y$. lipolytica.}

The TFs involved in SA and JA/ET signal pathways were selected and their expression levels were determined by real time-quantitative polymerase chain reaction (RT-qPCR). LOC103407103 and LOC103431866 were respectively annotated to 1-aminocyclopropane-1-carboxylate oxidase (ACO) and isochorismate synthase (SID). These two enzymes were induced by $Y$. lipolytica and belonged to the ET and SA pathways. The expression level of ACO in the yeast treatment group was 32-fold more than that of the control (Fig. 5A). The expression level of SID was also increased by 3.62 -fold due to the yeast treatment compared with the control (Fig. 5B). The results indicated that the antagonistic yeast $Y$. lipolytica induced disease resistance of the apples by the SA signal pathway.

The novel 00376 and LOC103437431 were annotated, respectively, to F-box protein (COI) and TF MYC3. COI (Fig. 5C)
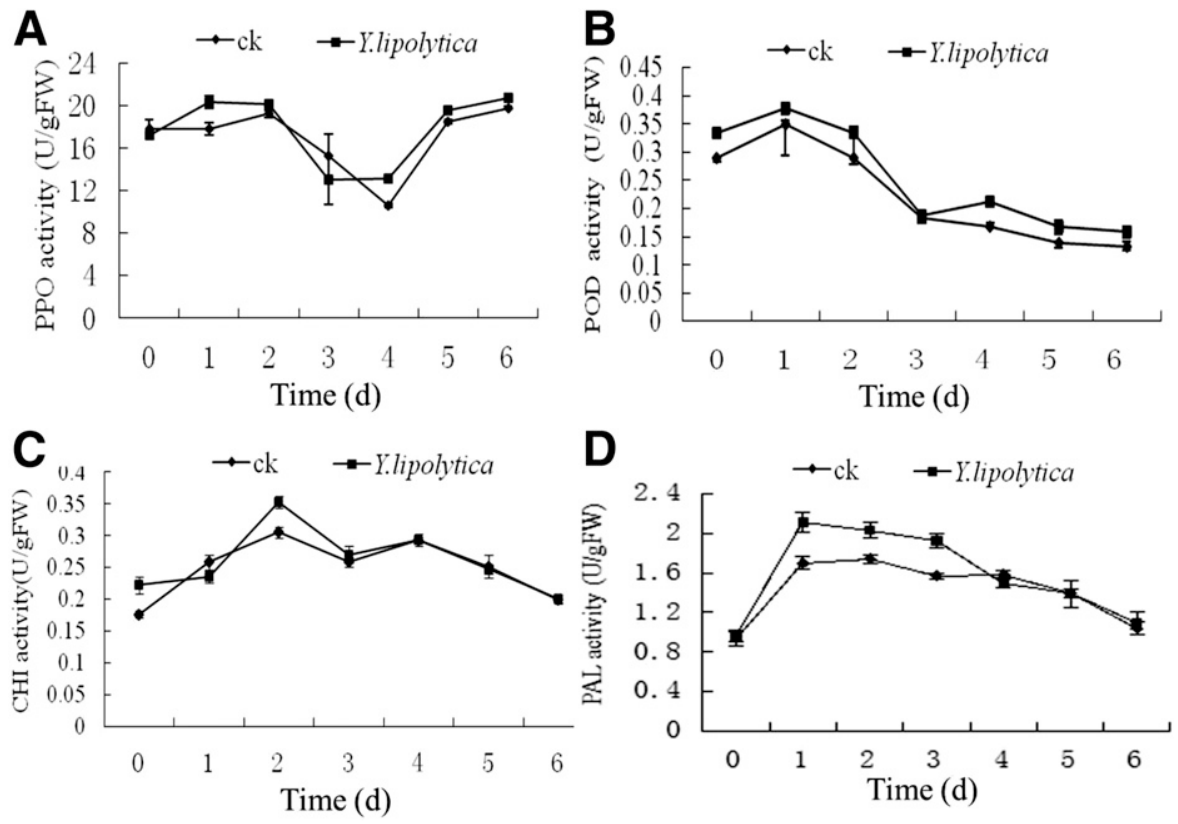

Fig. 2. Effect of Yarrowia lipolytica on the activities of A, polyphenoloxidase (PPO), B, peroxidase (POD), C, chitinase (CHI), and D, L-phenylalanine ammonia lyase (PAL) in apple wounds. 
and $M Y C 3$ (Fig. 5D) expression levels were each increased 28.25- and 9.49-fold when induced by $Y$. lipolytica compared with the control. LOC103439587 and LOC103422389, which were both stimulated by $Y$. lipolytica, were annotated as $E R F 2$ and ERF4, respectively. The expression levels of ERF2 (Fig. $5 \mathrm{E}$ ) and ERF4 (Fig. 5F) in the yeast treatment group were increased 8.28- and 3.43-fold compared with that of the control. These genes were all involved in the JA signal pathway and were induced by the yeast in apple fruits. The results indicated that the antagonist yeast $Y$. lipolytica induced the resistance of apple fruit through the JA/ET signal pathway. The expression levels of some other TFs were also analyzed. The WRKY family TFs were also found to be activated by $Y$. lipolytica (Fig. 5G). In addition, TIFY3B and TIFY11B, which are involved in JA signaling, were activated by the yeast, but the gene expression level was relatively low.

\section{Expression of defense response genes induced} by the SA and JA/ET signal pathways.

Expression of several defense response genes downstream of SA and JA/ET signal pathways was determined by RT-qPCR. The peroxidase (LOC103403867) (Fig. 6A), thaumatin-like protein $1 \mathrm{~b}$ (Fig. 6B), and chitinase 4-like (Fig. 6C) were increased 3.18-, 1.58-, and 3.56-fold, respectively, compared with the control. The most expressed gene was thaumatin-like protein 1a (LOC103426173), whose expression level was increased more than 35-fold compared with the control (Fig. 6D). LOC103434169 and LOC103402179, which were annotated to PR-4 (Fig. 6E) and PR protein-like (Fig. 6F) increased 25.57and 15.75-fold, respectively, by the yeast compared with the control. In addition, some defense response-related genes were also identified and are shown in Figure 6G. The expression level of PAL, acidic endochitinase-like, glutathione $S$-transferase, and polyphenol oxidase were increased more than twofold in apple treated with $Y$. lipolytica compared with the control.

\section{DISCUSSION}

The aim of this study was to determine the mechanism by which the yeast antagonist $Y$. lipolytica elicits disease resistance in apples. Y. lipolytica was proved to be an effective biocontrol agent against $P$. expansum in apples. The activities of disease resistance-related enzymes were activated in apple fruits when the yeast was inoculated into apple surface wounds. The proteome and transcriptome of both the yeast-treated apples and the control were analyzed. A total of 151 differentially expressed proteins were found, in which 77 were up-regulated and 74 were down-regulated. Among these proteins, we selected 35 highcontent proteins for analysis. GO and functional categories of the protein enrichment analysis showed that the main category among three was biological processes, and 13 functional proteins were associated with resistance response. A total of 607 DEGs were found, in which 229 genes were significantly up-regulated and 20 genes were significantly down-regulated by $Y$. lipolytica treatment. Functional categories of the DEGs by GO term enrichment analysis showed that defense and response-related genes were strongly induced by the yeast. Y. lipolytica is an oleaginous species of yeast that has numerous biotechnological applications in feed and food production (Groenewald et al. 2014; Morin et al. 2011). It also has been shown to have the activity of degrading ochratoxin A to nontoxic products (Yang et al. 2015). Y. lipolytica inhibited the growth of $P$. expansum in apple fruits, similar to results by Spadaro et al. (2013), who used Metschnikowia fructicola to control $P$. expansum and patulin accumulation in four cultivars of apples.

A successful biocontrol agent is generally equipped with several attributes that often work in concert and may be crucial
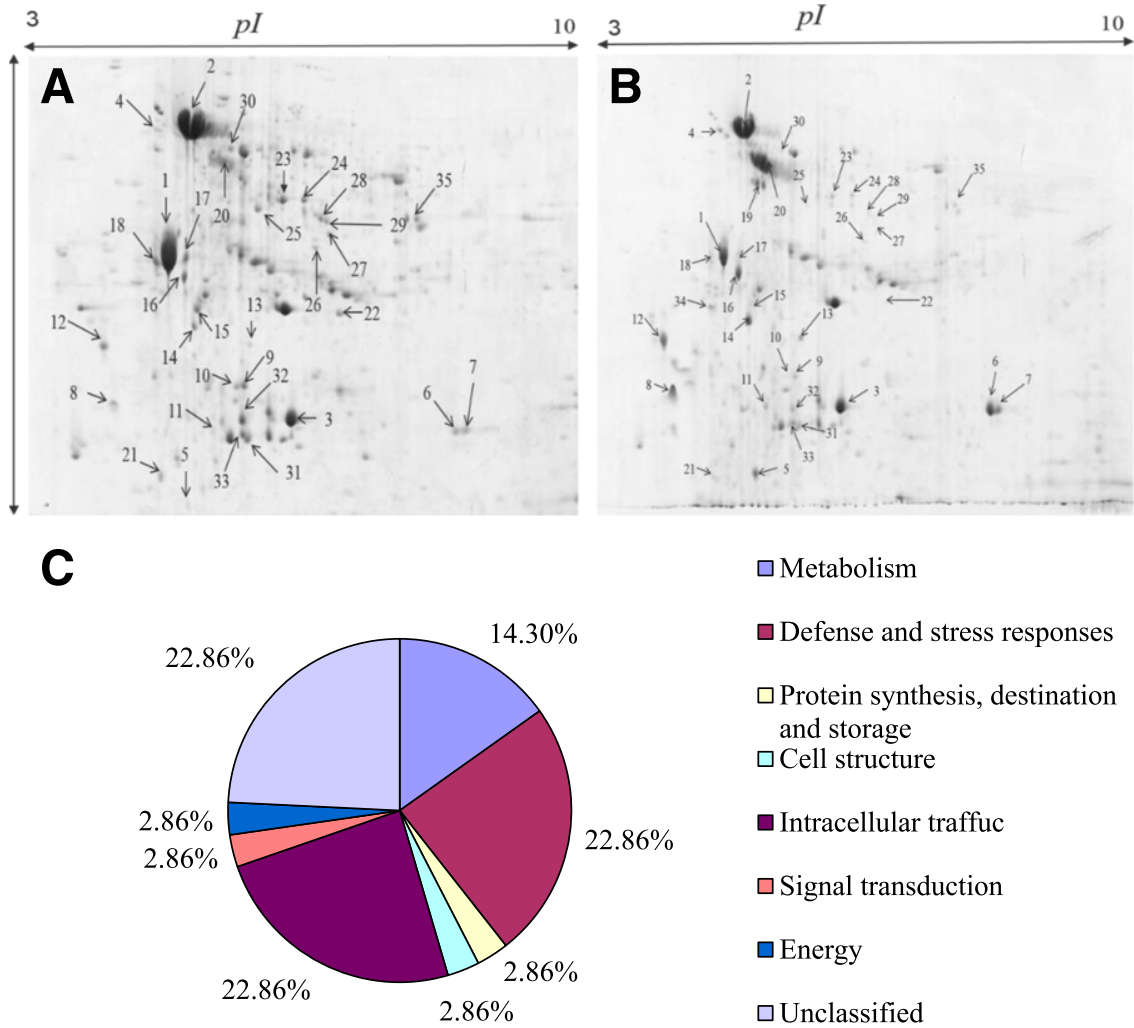

Fig. 3. Two-dimensional gels of apple proteins treated with Yarrowia lipolytica and the control at 3 days after different treatments. A, The control (nonyeast) and $\mathbf{B}$, the group treatment with Y. lipolytica (yeast) showed the protein spots. C, Proteins clustered by function. 
for controlling disease development (Droby et al. 2009). The ability to induce resistance through the activation of defenserelated enzymes was one important mechanism of action exhibited by the antagonist yeast. POD and CHI were induced by the antagonist Aureobasidium pullulans during apple storage (Ippolito et al. 2000). In addition, PAL, POD, CHI, and $\beta-1,3$ glucanase activities were found to be involved in the action of plant resistance induced by the yeast Cryptococcus laurentii (Yao and Tian 2005). In comparison with our study, the activities of PPO, POD, CHI, and PAL were also induced by $Y$. lipolytica in apples and these four enzymes were actively involved.

The ability to activate an SA-independent induced systemic resistance (ISR) pathway is common for beneficial microbes and occurs in a broad range of plant species (van Loon et al. 1998). In current work, $Y$. lipolytica treatment induced SID gene expression level, which was involved in the SA production pathway. The increased level of SA induced the expression of defense-related genes. Along with SA, plant hormones JA and ET are also important regulators of the plant immune system, COI has been described to have a central role in JA signaling for disease resistance against oomycetes and fungi. COI is a positive factor of the JA pathway (Chini et al. 2007; Glazebrook 2005). Gene expression of $C O I$ was increased when induced by $Y$. lipolytica in a robust manner. $A C O$ catalyzed the reaction from $S$-adenosyl methionine to ethylene in the ethylene biosynthetic pathway. ERF2 has a clear impact over $P D F 1.2$ gene expression by integrating JA/ET signals and ERF4 repressed PDF1.2 but induced VSP2 (Memelink 2009; Moffat et al. 2012). The expression level of ERF4 was increased, but the increased volume was much less than $C O I$ and ERF2 in the present research. The TF $M Y C 3$ is a key point of abscisic acid and JA signaling and regulates different response genes. $M Y C 3$ act additively with $M Y C 2$ in the activation of JA responses (Fernández-Calvo et al. 2011). TIF3B and TIF11B are two JAZ (JA-zim domain) family proteins that act as JA coreceptors and transcriptional repressors in JA signaling (Chini et al. 2007). In this study, LOC103442657 and LOC103443669 were annotated to JAZ proteins TIFY3B and TIFYIIB (Fig. 6E). They were triggered by the yeast but gene expression level was relatively low. The above results indicate that $Y$. lipolytica induced disease resistance of the apples by stimulating SA and JA/ET pathways, which mediated the defense response.

PR4 identified from Malus domestica was involved in defense responses against Botryosphaeria dothidea (Bai et al. 2013). PR4, as the response gene of downstream SA and JA signals, could be up-regulated by SA or methyl JA treatment. $P R 4$ was up-regulated by $Y$. lipolytica, indicating that SA and JA signal pathways were involved in induced resistance in apples. The resistance response was the result of crosstalk between SA and ET/JA pathways. Additionally, according to the proteome and transcriptome results, other defense-related proteins were also found. Thaumatin-like protein belong to the PR proteins 5 family, which has the antifungal ability to permeabilize fungal membranes and destroy cell walls of the pathogen using a series of enzymatic activities (Liu et al. 2010, 2012a and b). Ribonuclease-like PR-10c is homologous with the PR-10 that is an important PR protein in plant defense response (Gao et al. 2005; Liu and Ekramoddoullah 2006; Pulla et al. 2010). The expression level of peroxidase, PR protein, thaumatin-like protein $1 \mathrm{a}$, thaumatin-like protein $1 \mathrm{~b}$, and chitinase were higher than the control from the transcriptome data.

Table 1. Differentially expressed proteins identified in apple tissues after treatment

\begin{tabular}{|c|c|c|c|c|c|c|}
\hline Spot & Protein description & Accession no. & Mass & Organism & PI & Mascot score \\
\hline$\downarrow 1$ & Carbon monoxide dehydrogenase subunit $\mathrm{G}$ & gi|739834403 & 16,169 & $\begin{array}{l}\text { Sulfobacillus acidophilus } \\
\text { DSM } 10332\end{array}$ & 5.21 & 64 \\
\hline$\downarrow 2$ & Dehydrin 9 & gi|382948209 & 31,779 & Malus domestica & 5.2 & 233 \\
\hline$\downarrow 3$ & Ribonuclease-like PR-10c & gi| 15418742 & 17,694 & Malus domestica & 5.68 & 382 \\
\hline$\uparrow 4$ & Uncharacterized protein & gi| 657975084 & 49,883 & Malus domestica & 4.68 & 637 \\
\hline$\uparrow 5$ & Ribonuclease-like PR-10c & gi| 15418742 & 17,694 & Malus domestica & 5.68 & 419 \\
\hline$\uparrow 6$ & Thaumatin-like protein precursor Mdtl1 & gi|3643249 & 26,609 & Malus domestica & 5.17 & 145 \\
\hline$\uparrow 7$ & Thaumatin-like protein precursor Mdtl1 & gi|3643249 & 26,609 & Malus domestica & 5.17 & 78 \\
\hline$\uparrow 8$ & Aspartic proteinase & gi|21616051 & 57,088 & Malus domestica & 4.82 & 132 \\
\hline$\downarrow 9$ & Thaumatin-like protein precursor Mdtl1 & gi| 3643249 & 26,609 & Malus domestica & 5.17 & 77 \\
\hline$\downarrow 10$ & Peroxiredoxin-2B-like & gi| 657946863 & 17,550 & Malus domestica & 5.23 & 415 \\
\hline$\downarrow 11$ & Glutathione S-transferase-like & gi| 695055849 & 41,807 & Malus domestica & 7.06 & 267 \\
\hline$\uparrow 12$ & Thaumatin-like protein precursor Mdtl1 & gi| 3643249 & 26,609 & Malus domestica & 5.17 & 147 \\
\hline$\uparrow 13$ & $5^{\prime}-3^{\prime}$ Exoribonuclease 2-like & gi| 657979046 & 22,112 & Malus domestica & 6.09 & 318 \\
\hline$\uparrow 14$ & Thaumatin-like protein precursor Mdtl1 & gi| 3643249 & 26,609 & Malus domestica & 5.17 & 187 \\
\hline$\downarrow 15$ & Predicted protein & gi| 168033874 & 20,676 & Physcomitrella patens & 5.2 & 141 \\
\hline$\uparrow 16$ & Thaumatin-like protein precursor Mdtl1 & gi| 3643249 & 26,609 & Malus domestica & 5.17 & 299 \\
\hline$\downarrow 17$ & Acid phosphatase 1-like & gi| 658063964 & 29,032 & Malus domestica & 6.10 & 147 \\
\hline$\downarrow 18$ & Thaumatin-like protein precursor Mdtl1 & gi| 3643249 & 26,831 & Malus domestica & 4.71 & 289 \\
\hline$\uparrow 19$ & Dehydrin 9 & gi|382948209 & 31,779 & Malus domestica & 5.20 & 69 \\
\hline$\uparrow 20$ & Dehydrin 9 & gi|382948209 & 31,779 & Malus domestica & 5.20 & 113 \\
\hline$\downarrow 21$ & Profilin-1 & gi|1709779 & 14,462 & Arabidopsis thaliana & 4.70 & 96 \\
\hline$\downarrow 22$ & Glutathione $S$-transferase-like & gi $\mid 657955010$ & 23,877 & Malus domestica & 7.06 & 75 \\
\hline$\downarrow 23$ & Glutamine synthetase cytosolic isozyme-like & gi| 525507210 & 39,423 & Malus domestica & 5.78 & 188 \\
\hline$\downarrow 24$ & Glutamine synthetase cytosolic isozyme & gi 658036616 & 39,096 & Malus domestica & 5.78 & 115 \\
\hline$\downarrow 25$ & L-3-Cyanoalanine synthase 1 , mitochondrial & gi 658309724 & 41,085 & Malus domestica & 7.61 & 146 \\
\hline$\downarrow 26$ & Apolipoprotein D-like & gi 658003653 & 21,471 & Malus domestica & 6.18 & 192 \\
\hline$\downarrow 27$ & Probable aldo-keto reductase 2 & gi 657977050 & 37,340 & Malus domestica & 5.61 & 588 \\
\hline$\downarrow 28$ & Cytosolic malate dehydrogenase & gi|78216493 & 35,970 & Malus domestica & 6.01 & 299 \\
\hline$\downarrow 29$ & Cytosolic malate dehydrogenase & gi|78216493 & 35,817 & Malus domestica & 6.01 & 214 \\
\hline$\downarrow 30$ & ATP synthase subunit beta, mitochondrial & gi 658008796 & 60,115 & Malus domestica & 6.01 & 723 \\
\hline$\downarrow 31$ & Major allergen Mal d 1 & gi| 1313966 & 17,540 & Malus domestica & 5.72 & 170 \\
\hline$\downarrow 32$ & MLP-like protein 329 & gi| 658008681 & 17,823 & Malus domestica & 5.36 & 460 \\
\hline$\downarrow 33$ & Glycine-rich RNA-binding protein-like & gi| 658024705 & 16,877 & Malus domestica & 5.60 & 626 \\
\hline$\uparrow 34$ & Dehydrin 9 & gi|382948209 & 31,779 & Malus domestica & 5.20 & 477 \\
\hline$\downarrow 35$ & Major allergen Mal d 1 & gi| 2443824 & 17,514 & Malus domestica & 5.72 & 107 \\
\hline
\end{tabular}


It had been reported that $L e P R 5$ was up-regulated when postharvest cherry tomato fruits were treated by biocontrol yeast Cryptococcus laurentii, suggesting that LePR5 plays an important role in the defense system of cherry tomatoes and is involved in the biocontrol mechanism by inducing a resistance protein by yeast against pathogens in postharvest fruit (Guo et al. 2016). They also were consistent with PR-1a and PR-5, which induced elicitor responses to apple pathogen Erwinia amylovora (Bonasera et al. 2006). Previous studies have shown that PR-1, PR-3, and PR-4 genes were accumulated in M. domestica in response to pathogens (Bai et al. 2013; Gau et al. 2004). In this study, thaumatin-like protein 1a and thaumatin-like protein $1 \mathrm{~b}$, which were classified to the PR-5, were increased by $Y$. lipolytica, both in the transcriptome and proteome data. The PR genes were induced by $Y$. lipolytica, suggesting that $Y$. lipolytica could promote PR gene expression and enhance the ability of defense response (Fig. 6G). The expression of defense response genes in apple fruit was mediated by the SA and JA/ET signal pathway (Fig. 7).

\section{Concluding remarks.}

Our results demonstrated that $Y$. lipolytica induced the production of SA and ET signal in apple fruit. The SA and ET/JA signal mediated the defense pathway by henceforth stimulating the defense response genes. This led to the PR genes being upregulated to produce pathogen resistance in the apple fruits. Many genes were up-regulated, but not all of them had a positive effect on the SA and ET/JA signal pathway. Further detailed research on the specific role exhibited by each gene and their resultant interactions with each other is needed.

\section{MATERIALS AND METHODS}

Fruit source and yeast.

Apple fruits (Malus domestica Borkh 'Red Fuji') were harvested at commercial maturity. The apple fruits were treated according to the procedure described by Bevan et al. (1998). The antagonist yeast $Y$. lipolytica was obtained from a culture collection maintained by our laboratory. The yeast was cultured following the method described by Morin et al. (2011).

\section{Fruit inoculation and sample preparation.}

Three wounds were made, on the equator of each apple fruit, with a sterile cork borer (approximately $5 \mathrm{~mm}$ diameter and $3 \mathrm{~mm}$ deep). Each wound was inoculated with a $30-\mu \mathrm{l}$ suspension of $Y$. lipolytica $\left(1 \times 10^{6}\right.$ to $1 \times 10^{9}$ cells per milliliter $)$, and after $2 \mathrm{~h}$, was inoculated with a 30- $\mu \mathrm{l}$ suspension of P. expansum $\left(1 \times 10^{5}\right.$ spores per milliliter $)$, for analysis of the effect of $Y$. lipolytica in mold decay of apples caused by $P$. expansum. For enzyme activities, proteomic, and transcriptomic analysis, the apple wound was only inoculated with a 30- $\mu$ l suspension of $Y$. lipolytica at the concentration of $1 \times$ $10^{8}$ cells per milliliter and sterile distilled water was used as the control. The fruits were then placed in plastic trays, which were enclosed with polyethylene bags, to keep a high relative humidity (about $95 \%$ ), and were stored at $25^{\circ} \mathrm{C}$. After 3 days, the tissues of the wounds were taken out, were immediately frozen with liquid nitrogen, and were stored at $-80^{\circ} \mathrm{C}$, before processing. For the proteomic analysis, tissues were removed at $72 \mathrm{~h}$ for the quantification of relative mRNA levels.

\section{Analysis of enzyme activities of apple fruits.}

Extraction procedures were conducted at $4^{\circ} \mathrm{C}$. A quantity of $2 \mathrm{~g}$ of the fresh tissue around the wound from six apples was homogenized with $10 \mathrm{ml}$ of cold $50 \mathrm{mM}$ sodium phosphate buffer (pH 7.8) containing $1.33 \mathrm{mmol}$ of EDTA and $10 \mathrm{mg}$ per milliliter of polyvinylpolypyrrolidone. The homogenates were then centrifuged using a TGL-16 M centrifuge (XiangYi) at $12,000 \mathrm{rpm}$ at $4^{\circ} \mathrm{C}$ for $15 \mathrm{~min}$, and the supernatants were assayed. PPO activity was measured as described by Kiewning et al. (2013). POD activity was measured using the method described by Lurie et al. (1997), with some modifications by our research team

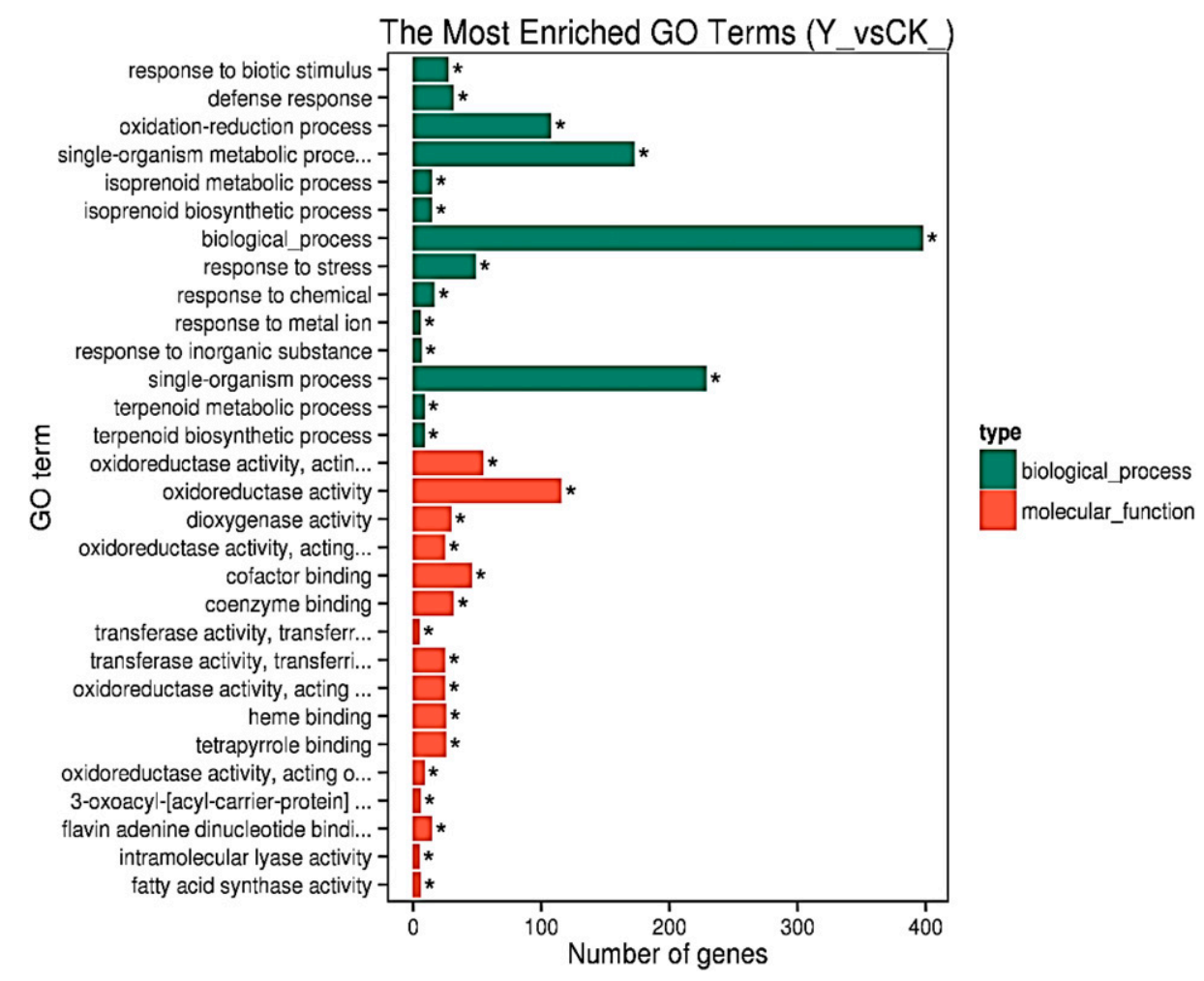

Fig. 4. Gene Ontology (GO) analysis of genes from the transcriptome data. 
(Zhao et al. 2013), using guaiacol as a substrate. CHI activity was measured using the method described by El Ghaouth et al. (2003), PAL activity was measured as described by Assis et al. (2001).

\section{Protein extraction and solubilization.}

Total protein was extracted from pooled samples using a phenol-based protocol (Spadaro et al. 2013). The tissues of apple wounds were ground into a fine powder in liquid nitrogen, using a mortar and pestle. The powder was subsequently suspended in an extraction buffer $(0.8 \mathrm{M}$ sucrose, $0.1 \mathrm{M}$ Tris- $\mathrm{HCl}$, pH 7.5, $10 \mathrm{mM}$ EDTA, 0.1 M KCl, $2 \mathrm{mM}$ phenylmethylsulfonyl fluoride, and $2 \% \beta$-mercaptoethanol), and an equal volume of Tris-saturated phenol ( $\mathrm{pH} 7.9)$ was added. The mixture was kept at $-20^{\circ} \mathrm{C}$ for 20 min and was vortexed every
$10 \mathrm{~min}$, and then, was centrifuged for $30 \mathrm{~min}$ at $10,000 \mathrm{rpm}$. The upper phenol phase was collected and the aqueous phase was re-extracted. The combined phenol phases were washed twice with extraction buffer. Then five volumes of cold methanol containing $0.1 \mathrm{M}$ ammonium acetate were added and kept at $-20^{\circ} \mathrm{C}$ overnight. After centrifugation at $10,000 \mathrm{rpm}$ for $20 \mathrm{~min}$, the precipitated protein pellets were washed, twice with cold methanol containing $0.1 \mathrm{M}$ ammonium acetate and twice with cold acetone. The pellets were then vacuum-dried and resolution in lysis buffer (7 M urea, $2 \mathrm{M}$ thiourea, $4 \%$ CHAPS, $1 \%$ dithiothreitol (DTT), $1 \%$ ampholyte, $\mathrm{pH} 3$ to 10$)$. Protein concentration was measured according to the methods of Spadaro et al. (2013) and Yao and Tian (2005), using bovine serum albumin as the standard. Two replicates were conducted
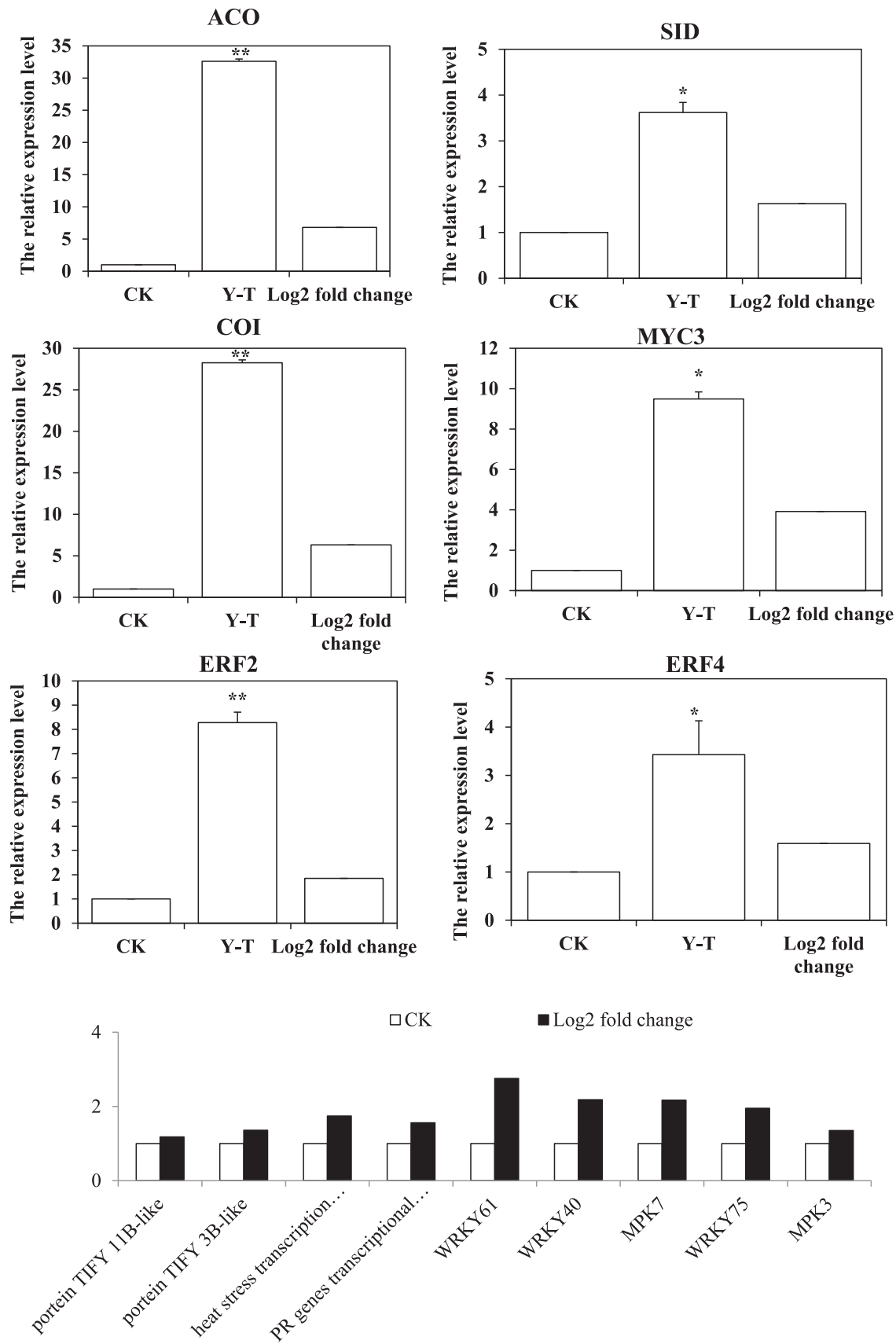

Fig. 5. The relative expression levels of the transcription factors involved in the salicylic acid and ethylene/jasmonate pathways. CK $=$ the control; Y-T $=$ the apple treated with Yarrowia lipolytica; $\log _{2}($ Fold change $)=$ the result acquired from the transcriptome data. One asterisk $(*)$ indicates significant difference $(P<0.05)$ and two asterisks $(* *)$ indicate extremely significantly difference $(P<0.01)$. 
for each step. The protein suspension was stored at $-80^{\circ} \mathrm{C}$ until 2-DE analysis.

\section{2-DE analysis.}

2-DE and image analysis were performed as described by van Loon et al. (1998), with some modifications. Proteins were first separated by isoelectric focusing (IEF), using a GE EttanIPGphor 3 and ImmobilineTM Drystrip gels $(24 \mathrm{~cm})(\mathrm{GE}$ Healthcare) with a nonlinear $\mathrm{pH}$ gradient (3 to 10), according to the manufacturer's instructions. After IEF, strips were equilibrated for $15 \mathrm{~min}$ in $10 \mathrm{ml}$ of equilibration buffer ( $7 \mathrm{M}$ urea, $2 \%$ sodium dodecyl sulfate, $0.075 \mathrm{Mtris}-\mathrm{HCl}, \mathrm{pH} 8.8,30 \%$
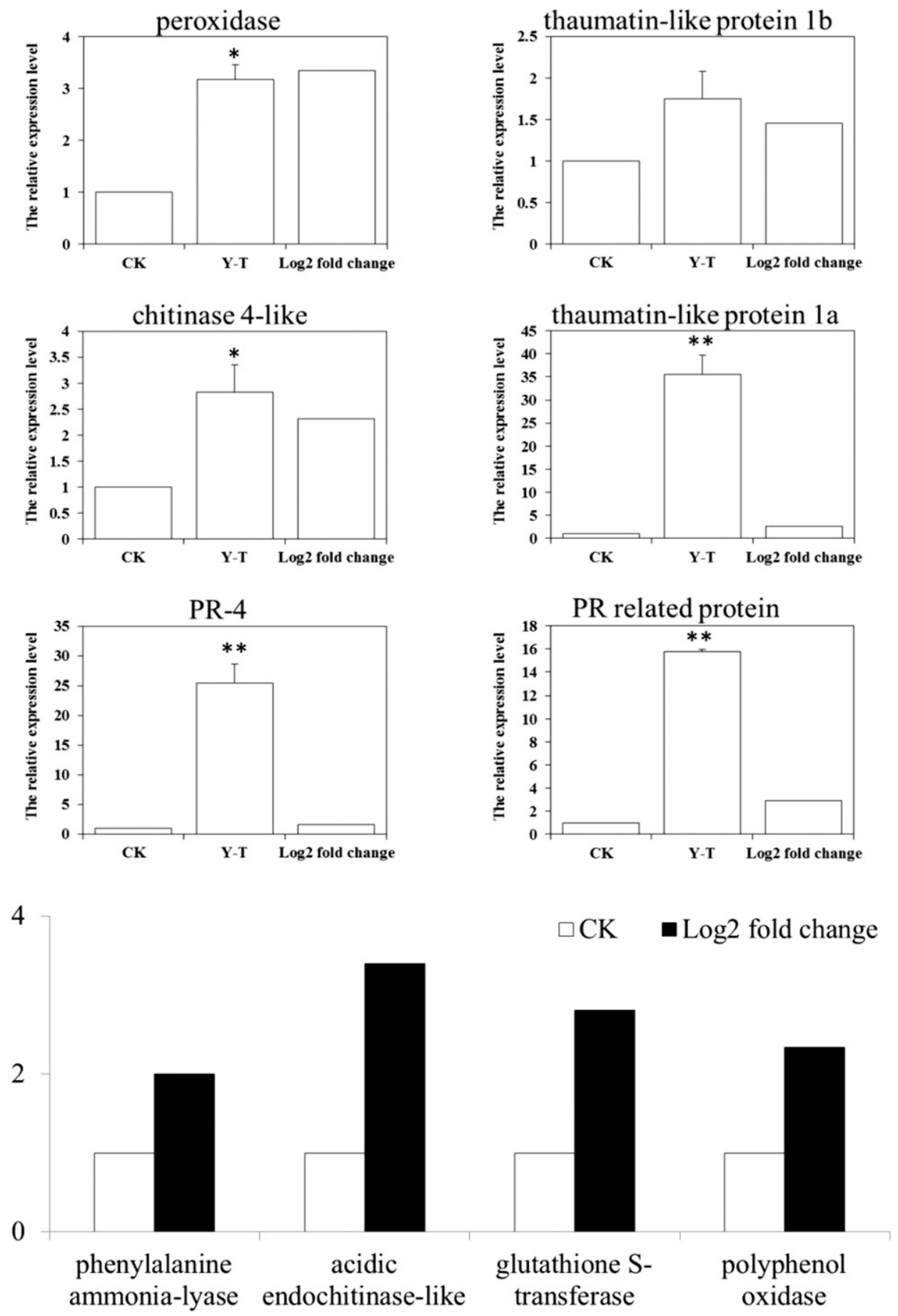

glycerol) containing 1\% DTT and, subsequently, for $15 \mathrm{~min}$ in $10 \mathrm{ml}$ equilibration buffer containing $2.5 \%$ iodoacetamide. The second dimensional electrophoresis was run on a $12 \%$ polyacrylamide gel in an Ettan DALT System (GE Healthcare). Protein spots in 2-DE gels were visualized by Coomassie blue staining. Three replicate gels were run for each sample. Image analysis was performed with the IPM7.0 software (GE Healthcare). A quality score of $<40$ was adopted to define lowquality protein spots, which were eliminated in further analysis (Fernández-Calvo et al. 2011; Memelink 2009). After normalization, only those spots with an average fold change $\geq 2$ at least at one point in time after treatment as well as those that
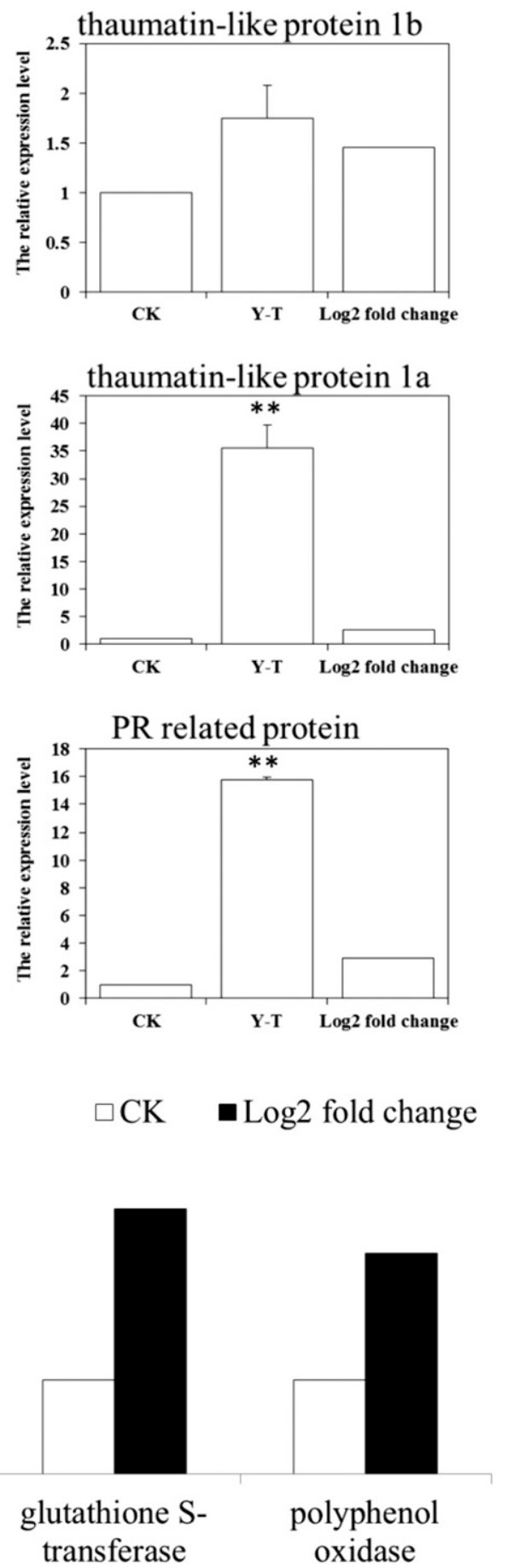

Fig. 6. The relative expression level of the pathogenesis-related (PR) genes. $\mathrm{CK}=$ the control; Y-T = the apple treated with Yarrowia lipolytica; log 2 (Fold change $)=$ the result acquired from the transcriptome data. One asterisk $(*)$ indicates significant difference $(P<0.05)$ and two asterisks $(* *)$ indicate extremely significantly difference $(P<0.01)$. 
exhibited the same expression pattern among the three replicates were considered as differentially expressed proteins (Liu et al. 2010). Proteins were first separated by IEF using a Protean IEF Cell and ReadyStrip IPG stripgels $(24 \mathrm{~cm})(\mathrm{GE}$ Healthcare) with a linear $\mathrm{pH}$ gradient of 4 to 7 , according to the manufacturer's instructions.

\section{In-gel digestion.}

Differentially expressed protein spots were excised manually from the gels and were destained with a $50 \mathrm{mM}$ ammonium bicarbonate, $50 \%$ acetonitrile solution. The gel pieces were then reduced in $10 \mathrm{mM}$ DTT for $45 \mathrm{~min}$ at $55^{\circ} \mathrm{C}$ and were alkylated in $55 \mathrm{mM}$ idoacetamide for $45 \mathrm{~min}$ at room temperature. After washing with $50 \%$ acetonitrile in $0.025 \mathrm{mM}$ $\mathrm{NH}_{4} \mathrm{HCO}_{3}$, the dried gels were incubated overnight at $37^{\circ} \mathrm{C}$ in $10 \mu \mathrm{l}$ of a $10-\mathrm{ng} / \mathrm{ml}$ solution of trypsin (Sigma-Aldrich). The supernatant was collected for MS analysis.

\section{MS analysis and database query.}

A sample of each peptide solution was mixed with an equal volume of a matrix solution $(70 \%$ acetonitrile, $0.1 \%$ trifluoroacetic acid, $10 \mathrm{mg}$ of $\alpha$-cyano- 4 hydroxycinnamic acid per milliliter). The mixture was immediately spotted onto the target plate and was dried at room temperature. MS data were obtained using an ultraflexmatrix-assisted laser desorption-ionization time-of-flight mass spectrometer. The resulting peptide mass fingerprinting (PMF) were queried against the National Center for Biotechnology Information non-redundant database, using MASCOT software with the following search parameters: viridiplantae (green plant), trypsin, up to one missed cleavage, carbamidomethylation of cysteine, peptide tolerance \pm 0.9 Dal, mass value $\mathrm{MH}+$ and monoisotopic.

Total RNA isolation, integrity, and quantification.

RNA was extracted according to the procedure of Liu et al. (2012a and b) with some modification. Diethyl pyrocarbonate (DEPC)-treated water was used for all solutions. The extraction buffer without $\beta$-mercaptoethanol (2\% CTAB, $2 \%$ polyvinylpyrrolidone $\mathrm{K}-30$ [soluble], $100 \mathrm{mM}$ Tris $\mathrm{HCl}$ [pH 8.0], $25 \mathrm{mM}$ EDTA, and $2.0 \mathrm{M} \mathrm{NaCl}$ ) was autoclaved and stored at room temperature, and $2 \% \beta$-mercaptoethanol was added before use. The protocol used was as follows. Frozen fresh apple tissue $(3 \mathrm{~g})$ was ground in liquid nitrogen, and then, the ground tissues

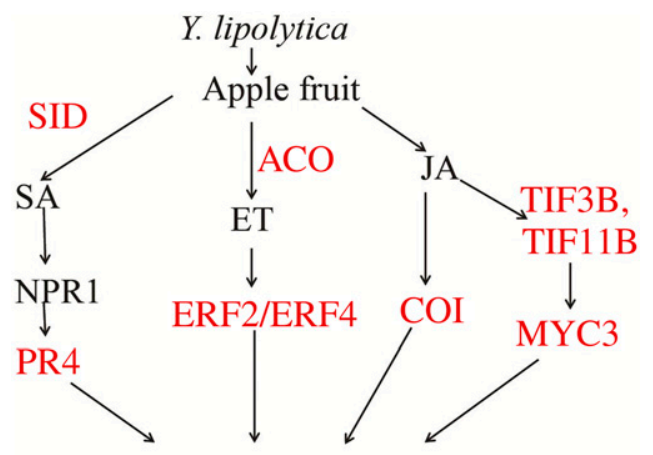

Defense genes expression level, enzymes activity was up-regulated

\section{Pathogen resistance}

Fig. 7. Salicylic acid (SA) and ethylene/jasmonate (ET/JA) signal pathways induced by Yarrowia lipolytica in apple fruit. Red words represent the genes that were up-regulated by the $Y$. lipolytica. were transferred into 50-ml polypropylene tubes with a chilled autoclaved spatula and were kept in liquid nitrogen until ready. Afterward, $10 \mathrm{ml}$ of preheated $\left(65^{\circ} \mathrm{C}\right.$ water bath) extraction buffer was added to each tube, and samples were vortexed and stored at $65^{\circ} \mathrm{C}$ for $10 \mathrm{~min}$. Samples were vortexed every $2 \mathrm{~min}$ during the period. RNAse were used to spray gloves occasionally. An equal volume of chloroform and isoamyl alcohol $(\mathrm{Chl}$ : Iaa) (24:1) was mixed and was immediately vortexed for 2 min. Samples were transferred to $50-\mathrm{ml}$ tubes that were cleaned and prelabeled and were then vortexed. The mixture was homogenized with a vortex in an ice bath for $10 \mathrm{~min}$ and, then, was centrifuged at $10,000 \mathrm{rpm}$ for $10 \mathrm{~min}$ at $4^{\circ} \mathrm{C}$. The supernatant was then transferred into a new tube. The aqueous phase was carefully pipetted and transferred into another tube, making sure that the white phase was not included. The mixture was reextracted with an equal volume of Chl:Iaa after centrifugation at $10,000 \mathrm{rpm}$ for $10 \mathrm{~min}$ at $4^{\circ} \mathrm{C}$. Thereafter, the supernatant was transferred again into a new 2-ml centrifuge tube (RNAse-free nonstick) by carefully pipetting all supernatant excluding the white layer. Steps 4 and 5 were repeated. Subsequently, the supernatant was transferred into a new 2-ml centrifuge tube and an equal volume of isoamylalcohol was added and the solution was vortexed. The supernatant was kept at room temperature for $10 \mathrm{~min}$ and was later centrifuged at $12,000 \mathrm{rpm}$ for $15 \mathrm{~min}$ at $4^{\circ} \mathrm{C}$, and the supernatant was discarded. Pellets were washed with $1 \mathrm{ml}$ of $75 \%$ ethanol-vortexed oscillator for about $5 \mathrm{~s}$ and, then, was centrifuged at 7,500 rpm for $1 \mathrm{~min}$. The remaining liquid was carefully pipetted and the pellets were air-dried for 5 to $10 \mathrm{~min}$ and were dissolved with an appropriate volume of DEPC-treated water. RNA was stored at $-80^{\circ} \mathrm{C}$. RNA degradation and contamination was monitored on $1 \%$ agarose gels. RNA purity was checked using the NanoPhotometer spectrophotometer (Implen) at wavelengths of 230, 260, and $280 \mathrm{~nm}$. RNA concentration was measured using the Qubit RNA assay kit in a Qubit 2.0 flurometer (Life Technologies). RNA integrity was assessed using the RNA Nano 6000 assay kit of the Bioanalyzer 2100 system (Agilent Technologies).

\section{Real-time-qPCR.}

RT-qPCR analyses were performed with independently generated samples from yeast treatments and control at the time. Primers for RT-qPCR were designed using the Primer 5 software and were synthesized by Sangon Biotech. cDNAs were reverse transcribed from $2 \mathrm{mg}$ of total RNA, using the PrimeScript RT reagent kit (Takara), and RT-qPCR analyses were performed on an ABI Prism 7500 real-time PCR system (Applied Biosystems). The apple ACTIN gene was used as an internal control to normalize the expression data (Liu and Ekramoddoullah 2006). Each RT-qPCR experiment was repeated three times. The relative expression of genes was calculated using the $2^{-\Delta \Delta \mathrm{Ct}}$ method (Gao et al. 2005), and standard deviation was calculated between three biological replicates. The gene-specific primers are listed in Supplementary Table S1.

\section{ACKNOWLEDGMENTS}

This work was supported by the National Key Research and Development Program of China (2016YFD0400902), the National Natural Science Foundation of China $(31571899,31271967)$, the Technology Support Plan of Jiangsu Province (BE2014372), and the Agricultural independent innovation fund in Jiangsu Province (CX(15)1048).

\section{LITERATURE CITED}

Adie, B. A., Pérez-Pérez, J., Pérez-Pérez, M. M., Godoy, M., SánchezSerrano, J. J., Schmelz, E. A., and Solano, R. 2007. ABA is an essential signal for plant resistance to pathogens affecting JA biosynthesis and the activation of defenses in Arabidopsis. Plant Cell 19:1665-1681. 
Assis, J. S., Maldonado, R., Muñoz, T., Escribano, M. I., and Merodio, C. 2001. Effect of high carbon dioxide concentration on pal activity and phenolic contents in ripening cherimoya fruit. Postharvest Biol. Technol. 23:33-39.

Bai, S., Dong, C., Li, B., and Dai, H. 2013. A PR-4 gene identified from Malus domestica is involved in the defense responses against Botryosphaeria dothidea. Plant Physiol. Biochem. 62:23-32.

Beckers, G. J., and Spoel, S. H. 2006. Fine-tuning plant defence signalling: Salicylate versus jasmonate. Plant Biol Stuttg 8:1-10.

Berrocal-Lobo, M., Molina, A., and Solano, R. 2002. Constitutive expression of ETHYLENE-RESPONSE-FACTOR1 in Arabidopsis confers resistance to several necrotrophic fungi. Plant J. 29:23-32.

Bevan, M., Bancroft, I., Bent, E., Love, K., Goodman, H., Dean, C., Bergkamp, R., Dirkse, W., Van Staveren, M., Stiekema, W., Drost, L., Ridley, P., Hudson, S. A., Patel, K., Murphy, G., Piffanelli, P., Wedler, H., Wedler, E., Wambutt, R., Weitzenegger, T., Pohl, T. M., Terryn, N., Gielen, J., Villarroel, R., De Clerck, R., Van Montagu, M., Lecharny, A., Auborg, S., Gy, I., Kreis, M., Lao, N., Kavanagh, T., Hempel, S., Kotter, P., Entian, K. D., Rieger, M., Schaeffer, M., Funk, B., Mueller-Auer, S., Silvey, M., James, R., Montfort, A., Pons, A., Puigdomenech, P., Douka, A., Voukelatou, E., Milioni, D., Hatzopoulos, P., Piravandi, E., Obermaier, B., Hilbert, H., Düsterhöft, A., Moores, T., Jones, J. D., Eneva, T., Palme, K., Benes, V., Rechman, S., Ansorge, W., Cooke, R., Berger, C., Delseny, M., Voet, M., Volckaert, G., Mewes, H. W., Klosterman, S., Schueller, C., and Chalwatzis, N. 1998. Analysis of $1.9 \mathrm{Mb}$ of contiguous sequence from chromosome 4 of Arabidopsis thaliana. Nature 391:485-488.

Bonasera, J. M., Kim, J. F., and Beer, S. V. 2006. PR genes of apple: Identification and expression in response to elicitors and inoculation with Erwinia amylovora. BMC Plant Biol. 6:23.

Brown, R. L., Kazan, K., McGrath, K. C., Maclean, D. J., and Manners, J. M. 2003. A role for the GCC-box in jasmonate-mediated activation of the PDF1.2 gene of Arabidopsis. Plant Physiol. 132:1020-1032.

Chan, Z., Qin, G., Xu, X., Li, B., and Tian, S. 2007. Proteome approach to characterize proteins induced by antagonist yeast and salicylic acid in peach fruit. J. Proteome Res. 6:1677-1688.

Charles, M. T., Tano, K., Asselin, A., and Arul, J. 2009. Physiological basis of UV-C induced resistance to Botrytis cinerea in tomato fruit. V. Constitutive defence enzymes and inducible pathogenesis-related proteins. Postharvest Biol. Technol. 51:414-424.

Chini, A., Fonseca, S., Fernández, G., Adie, B., Chico, J. M., Lorenzo, O. García-Casado, G., López-Vidriero, I., Lozano, F. M., Ponce, M. R., Micol, J. L., and Solano, R. 2007. The JAZ family of repressors is the missing link in jasmonate signalling. Nature 448:666-671.

Droby, S., Wisniewski, M., Macarisin, D., and Wilson, C. 2009. Twenty years of postharvest biocontrol research: Is it time for a new paradigm? Postharvest Biol. Technol. 52:137-145.

Droby, S., Wisniewski, M., Teixidó, N., Spadaro, D., and Jijakli, M. H. 2016. The science, development, and commercialization of postharvest biocontrol products. Postharvest Biol. Technol. 122:22-29.

El Ghaouth, A., Wilson, C. L., and Wisniewski, M. 2003. Control of postharvest decay of apple fruit with Candida saitoana and induction of defense responses. Phytopathology 93:344-348.

Fernández-Calvo, P., Chini, A., Fernández-Barbero, G., Chico, J.-M., Gimenez-Ibanez, S., Geerinck, J., Eeckhout, D., Schweizer, F., Godoy, M., Franco-Zorrilla, J. M., Pauwels, L., Witters, E., Puga, M. I., PazAres, J., Goossens, A., Reymond, P., De Jaeger, G., and Solano, R. 2011. The Arabidopsis bHLH transcription factors MYC3 and MYC4 are targets of JAZ repressors and act additively with MYC2 in the activation of jasmonate responses. Plant Cell 23:701-715.

Ferrari, S., Galletti, R., Denoux, C., De Lorenzo, G., Ausubel, F. M., and Dewdney, J. 2007. Resistance to Botrytis cinerea induced in Arabidopsis by elicitors is independent of salicylic acid, ethylene, or jasmonate signaling but requires PHYTOALEXIN DEFICIENT3. Plant Physiol. 144:367-379.

Fujita, M., Fujita, Y., Noutoshi, Y., Takahashi, F., Narusaka, Y., YamaguchiShinozaki, K., and Shinozaki, K. 2006. Crosstalk between abiotic and biotic stress responses: A current view from the points of convergence in the stress signaling networks. Curr. Opin. Plant Biol. 9:436-442.

Gao, Z. S., van de Weg, W. E., Schaart, J. G., Schouten, H. J., Tran, D. H., Kodde, L. P., van der Meer, I. M., van der Geest, A. H., Kodde, J., Breiteneder, H., Hoffmann-Sommergruber, K., Bosch, D., and Gilissen, L. J. 2005. Genomic cloning and linkage mapping of the Mal d 1 (PR-10) gene family in apple (Malus domestica). Theor. Appl. Genet. 111:171-183.

Gau, A. E., Koutb, M., Piotrowski, M., and Kloppstech, K. 2004 Accumulation of pathogenesis-related proteins in the apoplast of a susceptible cultivar of apple (Malus domestica cv. Elstar) after infection by Venturia inaequalis and constitutive expression of PR genes in the resistant cultivar Remo. Eur. J. Plant Pathol. 110:703-711.

Glazebrook, J. 2005. Contrasting mechanisms of defense against biotrophic and necrotrophic pathogens. Annu. Rev. Phytopathol. 43:205-227.

Groenewald, M., Boekhout, T., Neuvéglise, C., Gaillardin, C., van Dijck, P. W., and Wyss, M. 2014. Yarrowia lipolytica: Safety assessment of an oleaginous yeast with a great industrial potential. Crit. Rev. Microbiol. 40:187-206.

Guo, J., Zhao, X., Wang, H., Yu, T., Miao, Y., and Zheng, X. 2016 Expression of the lepr 5 gene from cherry tomato fruit induced by Cryptococcus laurentii and the analysis of lepr5 protein antifungal activity. Postharvest Biol. Technol. 111:337-344.

Hershkovitz, V., Ben-Dayan, C., Raphael, G., Pasmanik-Chor, M., Liu, J., Belausov, E., Aly, R., Wisniewski, M., and Droby, S. 2012. Globa changes in gene expression of grapefruit peel tissue in response to the yeast biocontrol agent Metschnikowia fructicola. Mol. Plant Pathol. 13:338-349.

Hoffmann-Sommergruber, K. 2002. Pathogenesis-related (PR) proteins identified as allergens. Biochem. Soc. Trans. 30:930-935.

Ippolito, A., El Ghaouth, A., Wilson, C. L., and Wisniewski, M. 2000. Control of postharvest decay of apple fruit by Aureobasidium pullulans and induction of defense responses. Postharvest Biol. Technol. 19: 265-272.

Jamalizadeh, M., Etebarian, H., Aminian, H., and Alizadeh, A. 2011. A review of mechanisms of action of biological control organisms against post-harvest fruit spoilage. EPPO Bulletin 41:65-71.

Kachroo, A., and Kachroo, P. 2007 Salicylic acid-, jasmonic acid-and ethylenemediated regulation of plant defense signaling. Pages 55-83 in Genetic engineering. Springer, Berlin.

Kiewning, D., Wollseifen, R., and Schmitz-Eiberger, M. 2013. The impact of catechin and epicatechin, total phenols and PPO activity on the Mal d 1 content in apple fruit. Food Chem. 140:99-104.

Liu, D., He, X., Li, W., Chen, C., and Ge, F. 2012a. Molecular cloning of a thaumatin-like protein gene from Pyrus pyrifolia and overexpression of this gene in tobacco increased resistance to pathogenic fungi. Plant Cell Tiss. Org. 111:29-39.

Liu, J., Wisniewski, M., Droby, S., Norelli, J., Hershkovitz, V., Tian, S., and Farrell, R. 2012b. Increase in antioxidant gene transcripts, stress tolerance and biocontrol efficacy of Candida oleophila following sublethal oxidative stress exposure. FEMS Microbiol. Ecol. 80:578-590.

Liu, J.-J., and Ekramoddoullah, A. K. 2006. The family 10 of plant pathogenesis-related proteins: Their structure, regulation, and function in response to biotic and abiotic stresses. Physiol. Mol. Plant Pathol. 68: $3-13$.

Liu, J.-J., Sturrock, R., and Ekramoddoullah, A. K. 2010. The superfamily of thaumatin-like proteins: Its origin, evolution, and expression towards biological function. Plant Cell Rep. 29:419-436.

Lorenzo, O., Chico, J. M., Sánchez-Serrano, J. J., and Solano, R. 2004. JASMONATE-INSENSITIVE1 encodes a MYC transcription factor essential to discriminate between different jasmonate-regulated defense responses in Arabidopsis. Plant Cell 16:1938-1950.

Lorenzo, O., Piqueras, R., Sánchez-Serrano, J. J., and Solano, R. 2003. ETHYLENE RESPONSE FACTOR1 integrates signals from ethylene and jasmonate pathways in plant defense. Plant Cell 15:165-178.

Lu, L., Wang, J., Zhu, R., Lu, H., Zheng, X., and Yu, T. 2015. Transcript profiling analysis of Rhodosporidium paludigenum-mediated signalling pathways and defense responses in mandarin orange. Food Chem. 172: 603-612.

Lurie, S., Fallik, E., Handros, A., and Shapira, R. 1997. The possible involvement of peroxidase in resistance to Botrytis cinerea in heat treated tomato fruit. Physiol. Mol. Plant Pathol. 50:141-149.

Macarisin, D., Droby, S., Bauchan, G., and Wisniewski, M. 2010. Superoxide anion and hydrogen peroxide in the yeast antagonist-fruit interaction: A new role for reactive oxygen species in postharvest biocontrol? Postharvest Biol. Technol. 58:194-202.

Magallon-Andalon, C., Luna-Solano, G., Ragazzo-Sanchez, J., and Calderon-Santoyo, M. 2012. Parasitism and substrate competitions effect of antagonistic yeasts for biocontrol of Colletotrichum gloeosporioides in papaya (Carica papaya L.) var Maradol. Mex. J. Sci. Res. 1:2-9.

McGrath, K. C., Dombrecht, B., Manners, J. M., Schenk, P. M., Edgar, C. I., Maclean, D. J., Scheible, W.-R., Udvardi, M. K., and Kazan, K. 2005. Repressor- and activator-type ethylene response factors functioning in jasmonate signaling and disease resistance identified via a genomewide screen of Arabidopsis transcription factor gene expression. Plant Physiol. 139:949-959.

Memelink, J. 2009. Regulation of gene expression by jasmonate hormones. Phytochemistry 70:1560-1570. 
Moffat, C. S., Ingle, R. A., Wathugala, D. L., Saunders, N. J., Knight, H., and Knight, M. R. 2012. ERF5 and ERF6 play redundant roles as positive regulators of JA/Et-mediated defense against Botrytis cinerea in Arabidopsis. PLoS One 7:e35995.

Morin, N., Cescut, J., Beopoulos, A., Lelandais, G., Le Berre, V., Uribelarrea, J.-L., Molina-Jouve, C., and Nicaud, J.-M. 2011. Transcriptomic analyses during the transition from biomass production to lipid accumulation in the oleaginous yeast Yarrowia lipolytica. PLoS One 6:e27966.

Petersen, M., Brodersen, P., Naested, H., Andreasson, E., Lindhart, U., Johansen, B., Nielsen, H. B., Lacy, M., Austin, M. J., Parker, J. E., Sharma, S. B., Klessig, D. F., Martienssen, R., Mattsson, O., Jensen, A. B., and Mundy, J. 2000. Arabidopsis map kinase 4 negatively regulates systemic acquired resistance. Cell 103:1111-1120.

Pulla, R. K., Lee, O. R., In, J.-G., Kim, Y.-J., Senthil, K., and Yang, D.-C. 2010. Expression and functional characterization of pathogenesis-related protein family 10 gene, PgPR10-2, from Panax ginseng CA Meyer. Physiol. Mol. Plant Pathol. 74:323-329.

Qin, G. Z., Tian, S. P., Xu, Y., and Wan, Y. K. 2003. Enhancement of biocontrol efficacy of antagonistic yeasts by salicylic acid in sweet cherry fruit. Physiol. Mol. Plant Pathol. 62:147-154.

Quaglia, M., Ederli, L., Pasqualini, S., and Zazzerini, A. 2011. Biological control agents and chemical inducers of resistance for postharvest control of Penicillium expansum Link. on apple fruit. Postharvest Biol. Technol. 59:307-315.

Santino, A., Taurino, M., De Domenico, S., Bonsegna, S., Poltronieri, P., Pastor, V., and Flors, V. 2013. Jasmonate signaling in plant development and defense response to multiple (a)biotic stresses. Plant Cell Rep. 32: 1085-1098.

Sharma, R., Singh, D., and Singh, R. 2009. Biological control of postharvest diseases of fruits and vegetables by microbial antagonists: A review. Biol. Control 50:205-221.

Shin, J., Heidrich, K., Sanchez-Villarreal, A., Parker, J. E., and Davis, S. J. 2012. TIME FOR COFFEE represses accumulation of the MYC2 transcription factor to provide time-of-day regulation of jasmonate signaling in Arabidopsis. Plant Cell 24:2470-2482.

Spadaro, D., and Droby, S. 2016. Development of biocontrol products for postharvest diseases of fruit: The importance of elucidating the mechanisms of action of yeast antagonists. Trends Food Sci. Technol. 47:39-49.

Spadaro, D., Lorè, A., Garibaldi, A., and Gullino, M. L. 2013. A new strain of Metschnikowia fructicola for postharvest control of Penicillium expansum and patulin accumulation on four cultivars of apple. Postharvest Biol. Technol. 75:1-8.

Spoel, S. H., Johnson, J. S., and Dong, X. 2007. Regulation of tradeoffs between plant defenses against pathogens with different lifestyles. Proc. Natl. Acad. Sci. U.S.A. 104:18842-18847.

Tian, S., Li, B., Qin, G., and Xu, X. 2011. Plant host response to biocontrol agents. Acta Hortic. 905:73-82.

Umar, U. D., Naqvi, S. A. H., Khan, A. A., Khan, S. M., Ateeq-ur-Rehman, Perveen, R., and Ejaz-ul-Haq, M. 2016. Management of Zucchini yellow mosaic virus in cucumber through genetic and salicylic acid induced resistance. Pak. J. Agric. Sci. 53:187-194.

van Loon, L. C., Bakker, P. A., and Pieterse, C. M. 1998. Systemic resistance induced by rhizosphere bacteria. Annu. Rev. Phytopathol. 36: 453-483.

van Loon, L. C., Rep, M., and Pieterse, C. M. 2006. Significance of inducible defense-related proteins in infected plants. Annu. Rev. Phytopathol. 44:135-162.

Wang, F., Feng, G., and Chen, K. 2009. Defense responses of harvested tomato fruit to burdock fructooligosaccharide, a novel potential elicitor. Postharvest Biol. Technol. 52:110-116.

Yang, Q., Wang, J., Zhang, H., Li, C., and Zhang, X. 2015. Ochratoxin A is degraded by Yarrowia lipolytica and generates non-toxic degradation products. World Mycotoxin J. 9:269-278.

Yao, H. J., and Tian, S. P. 2005. Effects of a biocontrol agent and methyl jasmonate on postharvest diseases of peach fruit and the possible mechanisms involved. J. Appl. Microbiol. 98:941-950.

Zhao, L., Zhang, H., Lin, H., Zhang, X., and Ren, X. 2013. Effect of trehalose on the biocontrol efficacy of Pichia caribbica against postharvest grey mould and blue mould decay of apples. Pest Manag. Sci. 69: 983-989.

\section{AUTHOR-RECOMMENDED INTERNET RESOURCE}

Matrix Science MASCOT software: http://www.matrixscience.com 